\title{
Вміст мінеральних компонентів у ротовій рідині дітей дошкільного віку з патологією опорно-рухового апарату
}

Резюме. Серед захворювань, що впливають на стоматологічний статус дітей, чільне місце займають порушення опорно-рухового апарату (ОРА). Склад та властивості ротової рідини є певним відображенням різноманітних фізіологічних та патологічних процесів в організмі та можуть допомогти вивчити ті ланки патогенезу карієсу зубів, які пов’язані з порушеннями ОРА.

Мета дослідження - визначити вміст мінеральних компонентів у ротовій рідині дітей із патологією ОРА та виявити зв'язок з інтенсивністю карієсу.

Матеріали і методи. Обстежено 90 дітей 5-ти років та поділено їх на III групи по 30 осіб у кожній: перша - діти з патологією ОРА та карієсом зубів; друга - дошкільнята з патологією ОРА на тлі недиференційованої дисплазії сполучної тканини (НДСТ) та карієсом зубів; третя - діти з карієсом зубів та без соматичної патології. Ураження тимчасових зубів карієсом визначали за індексом інтенсивності (кп), рівень інтенсивності карієсу за рекомендаціями П. А. Леуса (1989). Мінеральні компоненти ротової рідини визначали за допомогою фотометричного методу на біохімічному аналізаторі НumaStar=300 (Німеччина).

Результати досліджень та їх обговорення. Виявлено інтенсивність карієсу в дітей із патологією OPA - $(6,17 \pm 0,52)$ зуба, у дошкільнят із патологією ОРА на тлі НДСТ - $(8,00 \pm 0,50)$ зуба та у дітей групи порівняння - $(4,37 \pm 0,47)$ зуба. У дітей із патологією ОРА кількість загального кальцію у ротовій рідині на 33,80 \% менше відносно групи порівняння та на 25,53 \% більше, ніж у дітей із патологією ОРА на тлі НДСТ. Концентрація неорганічного фосфору в ротовій рідині дітей із патологією ОРА на 29,73 \% менше відносно групи порівняння і на 15,71 \% більше порівняно з дітьми при патології ОРА на тлі НдСТ. Така ж закономірність простежується і при аналізі вмісту магнію. Також встановлено зниження активності лужної фосфатази в ротовій рідині обох груп дітей із патологією ОРА порівняно зі здоровими дітьми.

Висновки. Результати обстеження свідчать, що в ротовій рідині дітей із патологією ОРА виявлено дефіцит загального кальцію, неорганічного фосфору, магнію та знижена активність лужної фосфатази.

Ключові слова: діти з патологією ОРА; карієс; мінеральні компоненти слини.

\author{
СН. И. Боднарук, Т. Ю. Лысак
}

Львовский национальный медицинский университет имени Данила Галицкого

\section{Содержание минеральных компонентов в ротовой жидкости детей дошкольного возраста с патологией опорно-двигательного апарата}

Резюме. Среди заболеваний, которые влияют на стоматологический статус детей, ведущее место занимают нарушения опорно-двигательного аппарата (ОДА). Состав и свойства ротовой жидкости является определенным отражением различных физиологических и патологических процессов в организме и могут помочь изучить звенья патогенеза кариеса зубов, связанных с нарушениями ОдА. Цель исследования - определить содержание минеральных компонентов в ротовой жидкости детей с патологией ОДА и выявить связь с интенсивностью кариеса.

Материалы и методы. Обследовано 90 детей 5-ти лет и разделено на III группы по 30 человек в каждой: первая - дети с патологией ОДА и кариесом зубов; вторая - дошкольники с патологией ОДА на фоне недифференцированной дисплазии соединительной ткани (НДСТ) и кариесом зубов; третья - дети с кариесом зубов и без соматической патологии. Пораженность временных зубов кариесом определяли по индексу интенсивности (кп), уровень интенсивности кариеса по рекомендациям П. А. Леуса (1989). Минеральные компоненты ротовой жидкости определяли фотометрическим методом на биохимическом анализаторе HumaStar=300 (Германия). 
Результаты исследований и их обсуждение. Выявлено интенсивность кариеса у детей с патологией ОДА - $(6,17 \pm 0,52)$ зуба, у дошкольников с патологией ОДА на фоне НДСТ - $(8,00 \pm 0,50)$ зуба и в детей группы сравнения - $(4,37 \pm 0,47)$ зуба. У детей с патологией ОДА количество общего кальция в ротовой жидкости на 33,80 \% меньше по отношению к группе сравнения и на 25,53 \% больше, чем у детей с патологией ОДА на фоне НДСТ. Концентрация неорганического фосфора в ротовой жидкости детей с патологией ОДА на 29,73 \% меньше относительно группы сравнения и на 15,71 \% по сравнению с детьми при патологии ОДА на фоне НДСТ. Такая же закономерность прослеживается и при анализе содержания магния. Также установлено снижение активности щелочной фосфатазы в ротовой жидкости обеих групп детей с патологией ОДА по сравнению со здоровыми детьми.

Выводы. Результаты обследования свидетельствуют, что в ротовой жидкости детей с патологией ОДА обнаружен дефицит общего кальция, неорганического фосфора, магния и снижена активность щелочной фосфатазы.

Ключевые слова: дети с патологией ОДА; кариес; минеральные компоненты слюны.

\author{
CN. I. Bodnaruk, T. Yu. Lysak \\ Danylo Halytskyi Lviv Medical University
}

\title{
Content of mineral components in the saliva of preschool children with musculoskeletal disorders
}

Summary. Musculoskeletal disorders (MSD) occupy a leading place among the diseases affecting the dental health of children. The composition and properties of the oral fluid are an appropriate reflection of the various processes in the body and can help to study the pathogenesis of tooth decay associated with MSD.

The aim of the study - to determine mineral ingredients composition of saliva in children with MSD and to identify its relationship with dental caries.

Materials and Methods. 90 5-year old children were examined and divided into three groups of 30 persons in each: first - children with dental caries and MSD; the second - children with dental caries, MSD and undifferentiated connective tissue disease (UCTD); the third - children with dental caries without somatic pathology (comparison group). The deft values and levels of caries prevalence were evaluated. Mineral components of the saliva were determined by photometric method.

Results and Discussion. The deft value was $(6.17 \pm 0.52)$ in children with MSD, $(8.00 \pm 0.50)$ in children with MSD and UCTD and (4.37 \pm 0.47$)$ in children of the comparison group. In children with MSD total calcium level in the saliva was $33.80 \%$ lower compared to that in comparison group and $25.53 \%$ higher than in children with MSD and UCTD. The concentration of inorganic phosphorus in the saliva of children with MSD was $29.73 \%$ lower compared to that in comparison group and $15.71 \%$ higher than in children with MSD and UCTD. The same pattern has shown the magnesium level. Alkaline phosphatase activity in the saliva of both groups of children with MSD was lower than in comparison group.

Conclusions. In the saliva of children with dental caries and MSD the deficiencies of total calcium, inorganic phosphorus and magnesium, as well as reduced activity of alkaline phosphatase were revealed.

Key words: children; MSD; dental caries; mineral components of saliva.

Вступ. Ротова рідина є зовнішнім середовищем для зубів і виконує важливу роль у формуванні резистентності тканин зуба до карієсу за рахунок постачання основних макро- та мікроелементів (кальцію, фосфору, фтору, магнію) в емаль зуба, зберігаючи при цьому рівновагу між процесами ре- та демінералізації (Е. В. Боровський, В. К. Леонтьєв, 1991). Згідно 3 дослідженнями [1, 2], склад та властивості ротової рідини є певним відображенням різноманітних фізіологічних та патологічних процесів в організмі та можуть допомогти вивчити ті ланки патогенезу карієсу зубів, які пов'язані з загальним станом організму. Серед патологічних станів, що впливають на стоматологічний статус дітей, чільне місце займають порушення опорно-рухового апарату (ОРА), які згідно з даними статистики, увійшли до першої п’ятірки найпоширеніших хвороб серед дитячого населення України [3]. Однією 3 головних причин змін стану ОРА у дітей $€$ недиференційована дисплазія сполучної тканини (НДСТ), що проявляється дестабілізацією структури сполучної тканини на системному рівні [4]. Тому оскільки сполучна тканина $є$ складовою усіх органів і систем, а в сучасній 
літературі недостатньо даних про зв'язок НДст із карієсом зубів, це питання $є$ актуальним i важливим для подальшої розробки протикаріозного профілактичного комплексу для дітей із патологією ОРА.

Метою дослідження було визначити вміст мінеральних компонентів (загального кальцію, магнію, неорганічного фосфору та активність лужної фосфатази) в ротовій рідині дітей із патологією опорно-рухового апарату та виявити зв'язок з інтенсивністю каріозного процесу.

Матеріали і методи. Для досягнення поставленої мети було обстежено 90 дітей 5-ти років, які відвідували дитячі садочки міста Львова, на базі яких є спеціалізовані групи для дітей із порушеннями ОРА. Усіх дітей поділили на III групи по 30 осіб у кожній: перша - діти з патологією ОРА та карієсом зубів; друга - дошкільніта з патологією ОРА на тлі НДСТ та карієсом зубів; третя - група порівняння - діти з карієсом зубів та без соматичної патології. Порушення ОРА оцінювали при використанні витягів із протоколів діагностичних засідань Львівської міської психолого-медико-педагогічної консультації. Стоматологічне обстеження дітей проводили 3 дозволу батьків та керівництва дошкільних закладів. Ураження тимчасових зубів карієсом визначали за індексом інтенсивності (кп). Рівень інтенсивності карієсу оцінювали за рекомендаціями П. А. Леуса (1989). Для дослідження мінеральних компонентів ротової рідини останню отримували шляхом спльовування (5 мл) в пробірки «Еппендорф» після попереднього полоскання порожнини рота дистильованою водою. Показники загального кальцію, неорганічного фосфору, магнію та лужної фосфатази в надосадковій фракції слини визначали фотометричним методом на біохімічному аналізаторі HumaStar=300 при використанні стандартних контрольних сироваток HUMATROL N, HUMATROL P фірми «HUMAN GmbH» (Німеччина). Концентрацію у ротовій рідині загального кальцію досліджували фотометрично за допомогою 0-крезолфталеїнового методу при використанні лізинового буфера $\mathrm{pH}=11,1$ азиду натрію; неорганічного фосфору - фотометричним методом, використовуючи реактив Molybdate; магнію фотометрично-колориметричним методом 3 використанням реактиву Gedta (одиниці вимірювання - в ммоль/л). Активність лужної фосфатази визначали колориметричним методом за допомогою діетаноламінового бу- фера (Buf) (одиниці вимірювання - у Од/л). Статистичну обробку отриманих результатів проводили у програмі Microsoft Excel та Statistica. Вірогідність результатів оцінювали за критерієм Стьюдента.

Результати досліджень та ї обговорення. Виявлено, що інтенсивність карієсу становить: у дітей із патологією ОРА - $(6,17 \pm 0,52)$ зуба, у дошкільнят з патологією ОРА на тлі НДСТ - $(8,00 \pm 0,50)$ зуба та у дітей групи порівняння - $(4,37 \pm 0,47)$ зуба. Результати дослідження ротової рідини показано на рисунку 1. Отже, встановлено, що найвищий вміст загального кальцію за середніми показниками виявлено в ротовій рідині дітей групи порівняння, а найнижчий (на 50,70 \% менше) у дошкільнят з патологією ОРА на тлі НДСТ $(1,42 \pm 0,07)$ до $(0,70 \pm 0,02)$ ммоль/л відповідно, $\mathrm{p}<0,001)$. У дітей із патологією ОРА кількість загального кальцію в ротовій рідині становить у середньому $(0,94 \pm 0,03)$ ммоль/л, що на 33,80 \% менше відносно групи порівняння та на 25,53 \% більше, ніж у дітей із патологією ОРА на тлі НДСТ.

Аналіз вмісту в ротовій рідині неорганічного фосфору показав найнижчі значення у дошкільнят з патологією ОРА на тлі НДСТ, що на 40,76 \% нижче відносно дітей групи порівняння і становить від $(2,63 \pm 0,05)$ ммоль/л до $(4,44 \pm 0,07)$ ммоль/л $(\mathrm{p}<0,001)$ відповідно. Концентрація неорганічного фосфору в ротовій рідині дітей із патологією ОРА становить $(3,12 \pm 0,06)$ ммоль/л і це на 29,73 \% менше відносно групи порівняння і на 15,71 \% більше порівняно з дошкільнятами при патології ОРА на тлі НДСТ.

Така ж закономірність була і при аналізі вмісту магнію в ротовій рідині. Так, у здорових дітей кількість магнію в середньому дорівнює $(2,22 \pm 0,05)$ ммоль/л, що на 64,86 \% більше, порівняно $з$ дітьми при патологї ОРА на тлі НДСТ $(0,78 \pm 0,04)$ ммоль/л, p<0,001 і на 53,60 \% більше, ніж у дошкільнят $з$ патологією ОРА $(1,03 \pm$ 0,04) ммоль/л, p<0,001. Аналіз за кількістю магнію між дітьми 3 патологією показав, що в ротовій рідині дошкільнят з патологією ОРА на тлі НДСТ вміст магнію на 24,27 \% нижчий відносно групи дітей із патологією ОРА.

Також встановлено зниження активності лужної фосфатази в обох групах дітей із патологією ОРА порівняно зі здоровими дітьми (рис. 2). Так, активність ЛФ у ротовій рідині дітей групи порівняння в середньому становить $(5,61 \pm 0,05)$ Од, тоді як у дошкільнят з патологією ОРА - $(5,03 \pm 0,06)$ Од/л, а у дітей із патологією 


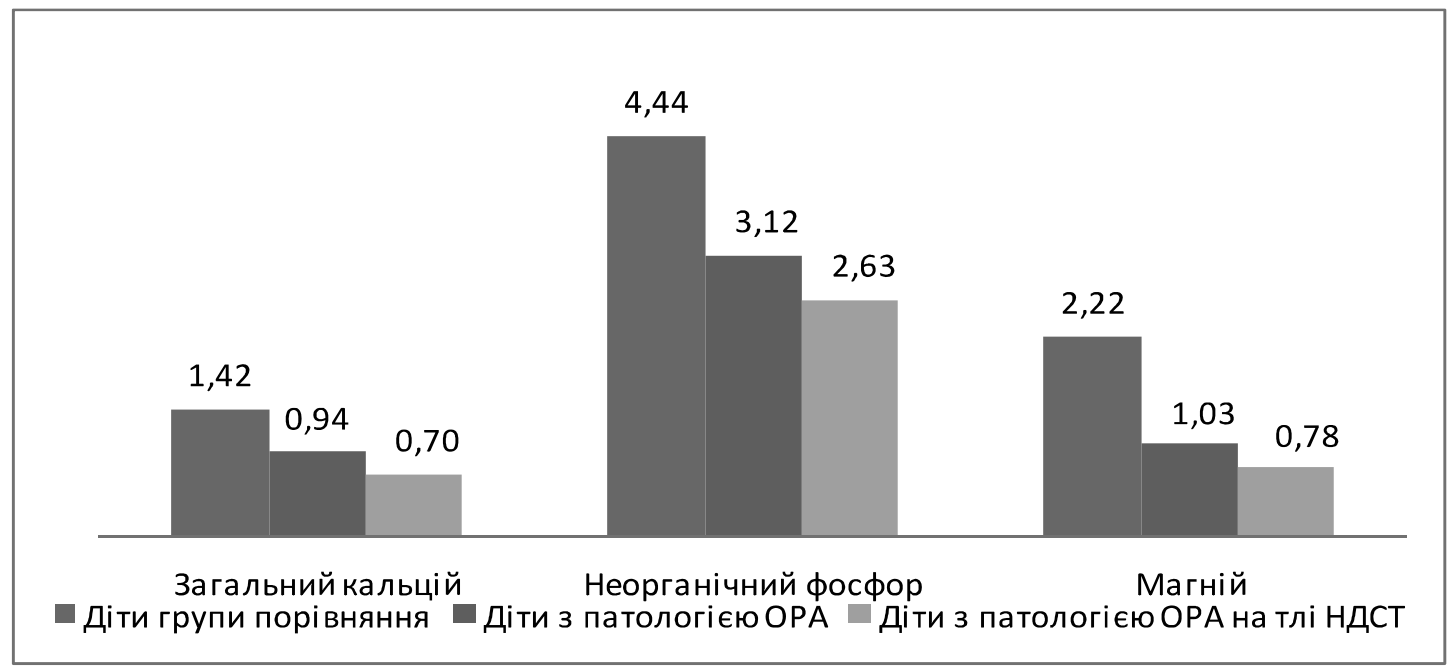

Puc. 1. Результати дослідження ротової рідини обстежених дітей 5-ти років (ммоль/л) (середні дані).

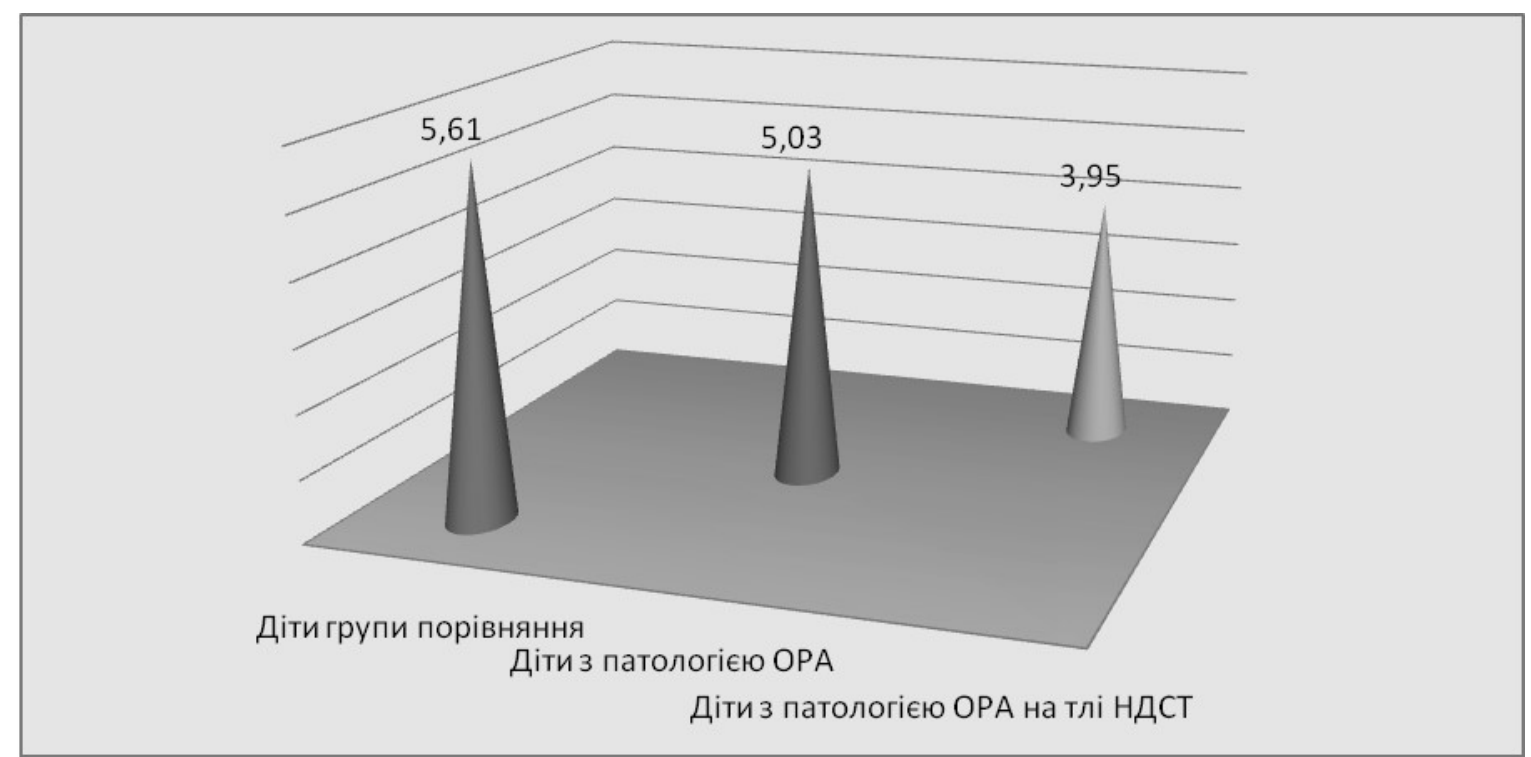

Puc. 2. Активність лужної фосфатази в ротовій рідині дітей 5-ти років (Од/л) (середні дані).

ОРА на тлі НДСТ лише $(3,95 \pm 0,05)$ Од/л, що відповідно на 10,34 та 29,60 \% нижче. Активність ЛФ у ротовій рідині дітей із патологією ОРА на тлі НДСТ на 21,47 \% нижча, ніж з патологією ОРА.

Проаналізовано показники мінеральних компонентів ротової рідини дітей із патологією ОРА залежно від рівня інтенсивності карієсу. Результати дослідження подано у таблиці. Згідно з даними дослідження, вміст загального кальцію в ротовій рідині дітей із патологією ОРА при низькому рівні інтенсивності карієсу (РІК) на 39,04 \% нижчий відносно дітей групи порівняння та становить від $(1,14 \pm 0,03)$ ммоль/л до $(1,87 \pm 0,04)$ ммоль/л відповідно ( $<0,001)$, а при дуже високому РІК на 23,00 \% і складає від $(0,87 \pm 0,15)$ ммоль/л до $(1,13 \pm 0,09)$ ммоль/л $(\mathrm{p}<0,01)$ відповідно.
Встановлено, що при підвищенні інтенсивності карієсу відбувається зниження концентрації загального кальцію в ротовій рідині як дітей із патологією ОРА, так і групи порівняння. Однак кількість кальцію у ротовій рідині здорових дітей, знижуючись від $(1,87 \pm 0,15)$ ммоль/л до $(1,13 \pm 0,09)$ ммоль/л $(\mathrm{p}<0,001)$, все ж залишається вищою відносно дошкільнят 3 патологією ОРА (від $(1,14 \pm 0,03)$ ммоль/л до $(0,87 \pm 0,04)$ ммоль/л, $\mathrm{p}<0,001)$ та дітей із патологією ОРА на тлі НДСТ (від $(0,76 \pm 0,04)$ ммоль/л до $(0,67 \pm 0,04)$ ммоль/л, $\mathrm{p}>0,05)$. Отже, у дітей із патологією ОРА вміст загального кальцію в ротовій рідині знижується лише на 21,19-26,31 \%, а у дітей із патологією ОРА на тлі НДСТ - на 36,44-42,86 \% відносно здорових дітей. Також встановлено, що 
у ротовій рідині дошкільнят із патологією ОРА на тлі НДСТ, порівняно $з$ дітьми з патологією ОРА, виявлено значно менший рівень загального кальцію при усіх рівнях інтенсивності карієсу. Так, найменшою є різниця при високому РІК (19,35 \%), а найбільшою - при дуже високому РІК (23,00 \%).

Таблищя. Концентрація загального кальцію, неорганічного фосфору, магнію в ротовій рідині дітей 5-ти років із патологією ОРА залежно від рівня інтенсивності карієсу (ммоль/л)

\begin{tabular}{|c|c|c|c|c|c|c|c|c|c|}
\hline \multirow{2}{*}{ Рік } & \multicolumn{3}{|c|}{ Діти з патологією ОРА } & \multicolumn{2}{|c|}{ Діти з патологією ОРА на тлі НдСТ } & \multicolumn{3}{c|}{ Діти групи порівняння } \\
\cline { 2 - 10 } & $\mathrm{Ca}$ & $\mathrm{P}$ & $\mathrm{Mg}$ & $\mathrm{Ca}$ & $\mathrm{P}$ & $\mathrm{Mg}$ & $\mathrm{Ca}$ & $\mathrm{P}$ & $\mathrm{Mg}$ \\
\hline Низький & $1,14 \pm 0,03^{*}$ & $3,36 \pm 0,06$ & $1,35 \pm 0,03$ & - & - & - & $1,87 \pm 0,15^{*}$ & $4,55 \pm 0,15$ & $2,44 \pm 0,02$ \\
\hline Середній & $0,98 \pm 0,03$ & $3,34 \pm 0,07$ & $1,30 \pm 0,03$ & $0,76 \pm 0,04^{* *}$ & $2,98 \pm 0,06$ & $0,85 \pm 0,04$ & $1,34 \pm 0,06$ & $4,61 \pm 0,15$ & $2,41 \pm 0,05$ \\
\hline Високий & $0,93 \pm 0,05$ & $3,21 \pm 0,06$ & $0,94 \pm 0,03$ & $0,75 \pm 0,05$ & $2,93 \pm 0,02$ & $0,82 \pm 0,04$ & $1,17 \pm 0,12$ & $4,34 \pm 0,19$ & $1,95 \pm 0,04$ \\
\hline $\begin{array}{c}\text { Дуже } \\
\text { високий }\end{array}$ & $0,87 \pm 0,04$ & $2,92 \pm 0,05$ & $0,87 \pm 0,04^{* * *}$ & $0,67 \pm 0,04^{* *}$ & $2,44 \pm 0,01$ & $0,75 \pm 0,06^{* * *}$ & $1,13 \pm 0,09$ & $4,18 \pm 0,13$ & $1,93 \pm 0,03$ \\
\hline
\end{tabular}

Примітки: 1) * достовірність різниці показників між дітьми з патологією ОРА та групою порівняння при різних рівнях інтенсивності карієсу ( $<<0,001)$;

2) ** - достовірність різниці показників між РІК у дітей із патологією ОРА на тлі НДСТ (р>0,05);

$3)^{* * *}$ - достовірність різниці між показниками у дітей із патологією ОРА та з патологією ОРА на тлі НДСТ ( $\left.<0,02\right)$.

Вивчення вмісту неорганічного фосфору в ротовій рідині обстежених дітей виявило тенденцію до його зниження при підвищенні показників РІК в усіх групах. Але якщо у здорових дітей показники неорганічного фосфору знижуються лише на 8,13\% (від $(4,55 \pm 0,15)$ ммоль/л при низькому РІК до $(4,18 \pm 0,13)$ ммоль/л при дуже високому РІК, p>0,05), то у дошкільнят 3 патологією ОРА - на 13,03 \% (від $(3,36 \pm 0,06)$ ммоль/л до $(2,92 \pm 0,05)$ ммоль/л відповідно, $p<0,001)$, більш помітно зменшуючись при множинному каpiєсі. Найбільше зменшення концентрації неорганічного фосфору (на 13,03 \%) відмічено у дітей при патології ОРА на тлі НДСТ (від $(2,98 \pm 0,06)$ ммоль/л при середньому РІК до $(2,44 \pm 0,01)$ ммоль/л при дуже високому РІК, $\mathrm{p}<0,001)$. Результати порівнянь показників неорганічного фосфору між групами дітей із патологією виявили нижчі значення у дітей із патологією ОРА на тлі НДСТ порівняно з дітьми 3 патологією ОРА. Різниця між показниками зростає від 10,77 до 16,44 \% при підвищенні рівня інтенсивності карієсу. При порівнянні зі здоровими дітьми, більш суттєву різницю виявлено у дошкільнят з патологією ОРА на тлі НДСТ. Так, вміст фосфору в них нижчий на $35,36-41,63 \%$, тоді як у дітей із патологією ОРА - лише на 26,15-30,14\%.

Оцінюючи концентрації магнію в ротовій рідині обстежених дітей, виявлено певну закономірність, при якій спостерігається значне його зниження при всіх рівнях інтенсивності карієсу в обох групах дітей із патологією ОРА відносно дітей групи порівняння. Встановлено, що у ротовій рідині дошкільнят з патологією ОРА на тлі НДСТ концентрація магнію знижується від $(0,85 \pm 0,04)$ ммоль/л при середньому РІК до $(0,75 \pm 0,06)$ ммоль/л при дуже високому PIК (p>0,05), що на 64,73-82,06 \% нижче відносно дітей групи порівняння, у яких кількість магнію в ротовій рідині $є$ найвищою і становить $(2,44 \pm 0,02)$ ммоль/л та $(1,93 \pm 0,03)$ ммоль/л відповідно $(\mathrm{p}<0,001)$. У ротовій рідині дітей із патологією ОРА вміст магнію достовірно знижується від $(1,35 \pm 0,03)$ ммоль/л до $(0,87 \pm 0,04)$ ммоль/л $(\mathrm{p}<0,001)$ і є на 46,67 $55,00 \%$ нижче відносно дошкільнят групи порівняння. Результати аналізу показників концентрації магнію в ротовій рідині дітей із патологією виявили певну особливість, при якій при підвищенній інтенсивності карієсу різниця у кількості магнію значно знижується. Так, при середньому РІК вміст магнію в ротовій рідині дітей із патологією ОРА становить $(1,30 \pm 0,03)$ ммоль/л, а у дітей 3 патологією ОРА на тлі НДСТ - на 34,61 \% менше і дорівнює $(0,85 \pm 0,04)$ ммоль/л $(\mathrm{p}<0,001)$. При дуже високому РІК різниця між показниками від $(0,87 \pm 0,04)$ ммоль/л у дітей з патологією ОРА до $(0,75 \pm 0,06)$ ммоль/л у дітей із патологією ОРА на тлі НДСТ $(\mathrm{p}<0,02))$ зменшилась до $13,79 \%$.

Важливим компонентом процесу мінералізації твердих тканин зуба є лужна фосфатаза. Визначення активності лужної фосфатази виявило суттєве її зниження у ротовій рідині дітей із патологією ОРА відносно до дітей групи порівняння (рис. 3). Також активність ЛФ 


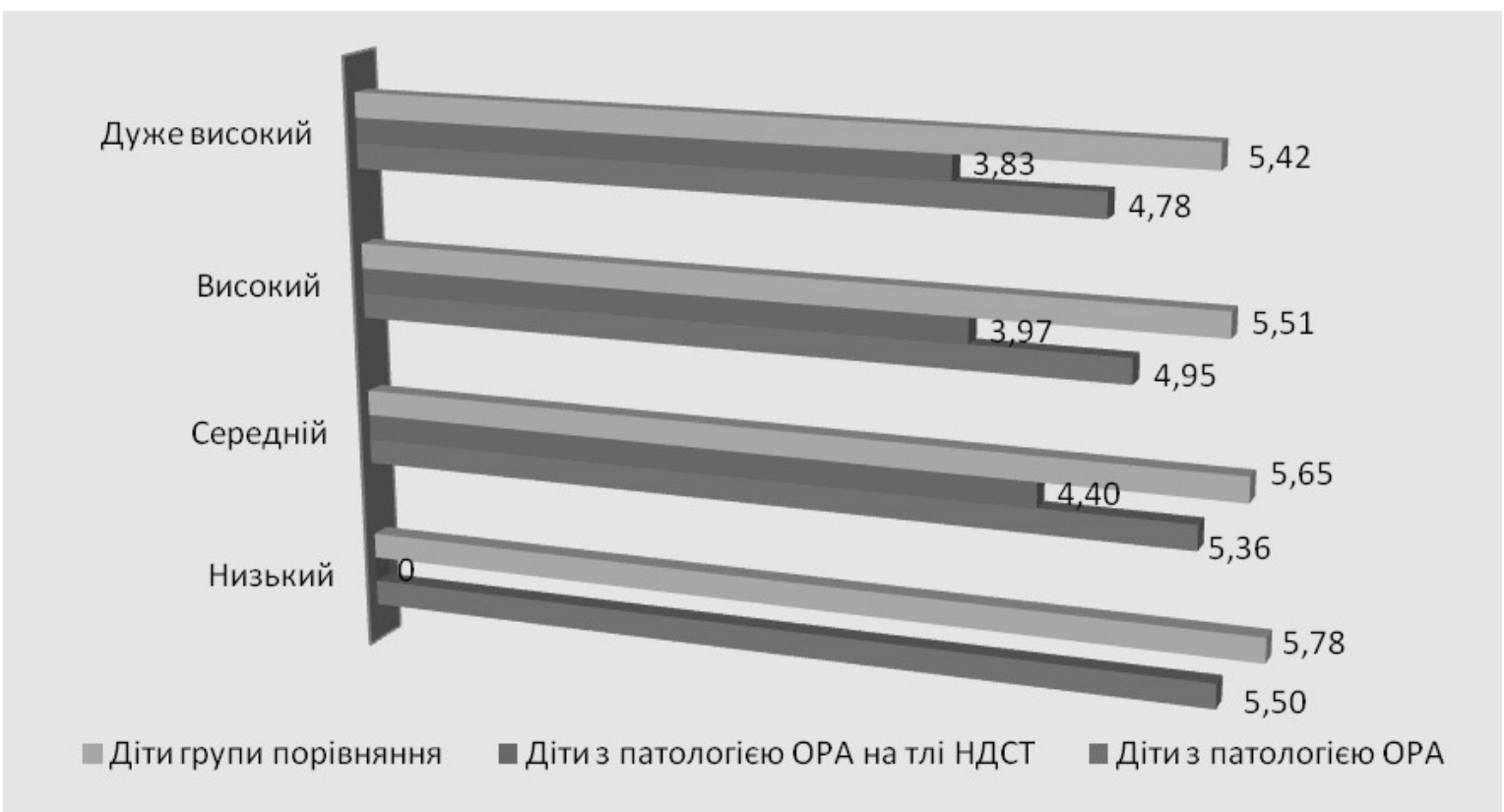

Puc. 3. Активність лужної фосфатази у дітей 5-ти років із патологією ОРА залежно від рівнів інтенсивності каріесу (Од/л).

знижувалась при підвищенні рівня інтенсивності карієсу у всіх групах обстеження. Так, найвищою активність ЛФ була у дітей групи порівняння і при підвищенні РІК зменшилась лише на 6,22 \% (від $(5,78 \pm 0,08)$ Од/л при низькому РІК до $(5,42 \pm 0,09)$ Од/л при дуже високому PІК, $\mathrm{p}<0,01)$, тоді, як у дошкільнят із патологією ОРА активність ЛФ знизилась на $13,09 \%$ (від $(5,50 \pm 0,09)$ Од/л до $(4,78 \pm 0,07)$ Од/л, $\mathrm{p}<0,001)$, а в дітей із патологією ОРА на тлі НдСТ - майже на 13,00 \% (від $(4,40 \pm 0,05)$ Од/л при середньому РІК до $(3,83 \pm 0,05)$ Од/л при дуже високому РІК, $\mathrm{p}<0,001)$. Також встановлено, що у дітей з патологією ОРА активність

\section{Список літератури}

1. Ткаченко В. И. Минеральный состав ротовой жидкости и состояние твердых тканей зубов у детей со склерозом, проживающих во фтористой провинции / В. И. Ткаченко, Н. Н. Коротич // Вісник стоматології. - 2001. - № 2. - С. 38-40.

2. Самойленко А. В. Вивчення біохімічних показників метаболізму кісткової тканини в пацієнтів із зубощелепними аномаліями, ускладненими захворюваннями пародонта, на тлі сколіозу / А. В. Самойленко, В. О. Дрок, Т. О. Пиндус // Український стоматологічний альманах. - 2012. - № 6. - С. 17-19.

\section{References}

1. Tkachenko, V.I. \& Korotich, N.N. (2001). Myneralnyi sostav rotovoy zhydkosti i sostoyanie tverdykh tkaney zubov $u$ detey so sklerozom, prozhyvayushchykh vo ftoristoy provintsyy [Mineral composition of oral fluid and the state of hard tooth tissues in children
ЛФ була вищою, ніж у дошкільнят при патології ОРА на тлі НДСТ, зокрема при середньому РІК на 17,91 \%, а при дуже високому РІК на $19,87 \%$.

Висновки. Отримані результати свідчать, що в ротовій рідині дітей із патологією ОРА виявлено дефіцит загального кальцію, неорганічного фосфору, магнію та знижена активність лужної фосфатази. У дошкільнят з патологією ОРА на тлі НДСТ недостатність цих мінеральних компонентів більш виражена, що відображається на зниженні резистентності емалі до карієсу та підвищенні інтенсивності карієсу відповідно.

3. Аксьонова С. Ю. Державна доповідь про становище дітей в Україні (за підсумками 2011 року) / С. Ю. Аксьонова, М. Ю. Варбан, О. А. Васильєв. - К., 2012. -188 c.

4. Калиниченко I. О. Зміни стану постави та склепіння ступні у дітей 4-6 років із гіпермобільністю суглобів під впливом реабілітаційних заходів в умовах навчальних закладів / I. О. Калиниченко, Ю. Л. Дяченко // Педагогіка, психологія та медикобіологічні проблеми фізичного виховання і спорту.2013. - № 8 - С. 26-30.

with sclerosis, living in the fluoride province]. Visnyk stomatolohii - Journal of Stomatology, (2), 38-40 [in Ukrainian].

2. Samoilenko, A.V., Drok, V.O. \& Pyndus, T.O. (2012). Vyvchennia biokhimichnykh pokaznykiv metabolizmu 
kistkovoi tkanyny $\mathrm{v}$ patsiientiv iz zuboshchelepnymy anomaliiamy, uskladnenymy zakhvoriuvanniamy parodonta, na tli skoliozu [Study of biochemical parameters of bone metabolism in patients with dentofacial anomalies, complicated diseases of periodontal disease, against scoliosis]. Ukrainskyi stomatolohichnyi almanakh - Ukrainian Dental Almanac, (6), 17-19 [in Ukrainian].

3. Aksonova, S.Yu., Varban, M.Yu., \& Vasyliev, O.A. (2012). Derzhavna dopovid pro stanovyshche ditei v Ukraini (za pidsumkamy 2011 roku). [State report on the situation of children in Ukraine (in 2011)]. Kyiv [in Ukrainian].
4. Kalynychenko, I.O. \& Diachenko, Yu.L. (2013). Zminy stanu postavy ta sklepinnia stupni u ditey 4-6 rokiv iz hipermobilnistiu suhlobiv pid vplyvom reabilitatsiinykh zakhodiv $\mathrm{v}$ umovakh navchalnykh zakladiv [State changes in posture and arch of the foot in children aged 4-6 years with hypermobility of the joints under the influence of rehabilitation activities in schools]. Pedahohika, psykholohiia ta medyko-biolohichni problemy fizychnoho vykhovannia i sportu - Pedagogy, Psychology and Medico-biological Problems of Physical Education and Sport, (8), 26-30 [in Ukrainian].

Отримано 14.09.17 